\title{
MOTIVASI PETANI MENANAM CABE (Capsicum Annum L) DI KECAMATAN LEMBAH GUMANTI KABUPATEN SOLOK
}

\author{
Lina Delvita \\ Program Studi Pendidikan Geografi STKIP PGRI Sumatera BArat \\ delvitalina@gmail.com
}

\begin{abstract}
Background of this research is motivation of farmer chili plant of land prepation, production, and price in chili plant process and the purposes for obtain information, analyze and discuss about motivation of farmer chili plant in Lembah Gumanti Subdistrict Solok Regency.Kinds of the research used qualitative research. The informant used snowball sampling is accumulation sample technique beginning small quantity, then large ther informant in thisresearch is society a chili plant. Technique of collect data used observation, interview and documentation. Technique of data analysis is reduction data, data display and verification. Research findings are 1) The motivasion of farmer chili plant see from land preparation don't difficult very motivate the farmer in chili plant, the farmer not load although obstaste for land preparation for chili plant. 2) The motivation of farmer chili plant see from productionlevel the advance very motivate farmer in chili plant, until increase farmer income and need fill every day. 3) The motivasion of farmer chili plant see from chili price a high very motivate farmer in chili plant, until increase economy ability farmer chili plant in Galagah.

Keyword : motivation, farmer chili plant
\end{abstract}

\section{PENDAHULUAN}

Indonesia adalah negara yang kaya akan sumber daya alam, SDA ini sangat berperan penting dalam kegiatan produksi, terutama pada sektor pertanian dan perkebunan. Salah satu kegiatan non pertanian migas yang perlu dikembangkan adalah sumber daya lahan. Pertanian merupakan suatu aktivitas manusia yang disengaja, dengan memanfaatkan lahan yang kosong untuk ditumbuhi berbagai macam jenis tanaman pertanian. Kegiatan ini berhubungan dengan pemberdayaan masyarakat melalui revitalisasi sektor pertanian dengan menggunakan lahan sebagai daya dukung. Jika kegiatan pertanian dalam arti luas dilakukan sesuai dengan kemampuan lahannya, maka akan membuka lapangan kerja yang dapat menyerap banyak tenaga kerja dan menghindari terjadinya pengangguran, (Bonawati dan Sriyanto, 2013: 3)

Sumber daya lahan untuk tiap-tiap daerah (wilayah) berbeda atau bervariasi, variasi tersebut tergantung pada faktor lingkungan fisik maupun lingkungan manusia. Oleh sebab itu manusia harus mengetahui penggunaan lahan, beserta informasi tentang lahan sangat diperlukan dalam pemanfaatan lahan (Elmiati, 2000). 
Lahan merupakan lingkungan fisik dan biofisik yang berkaitan dengan daya dukungnya terhadap perikehidupan dan kesejahteraan hidup manusia, lingkungan fisik meliputi relief (topografi). iklim, tanah, air dan penggunaan lahan keseluruhannya saling berinteraksi. Jika dilihat dari kegunaan lahan, lahan memiliki kegunaan yang beragam bagi kehidupan manusia sebagai tempat terjadinya interaksi sosial, budaya dan ekonomi, namun lahan merupakan tempat tumbuh dan berkembang berbagai macam tanaman, baik tanaman pangan maupun tanaman non pangan dan tanaman jangka panjang maupun jangka pendek. Segala aktivitas tanaman berlangsung diatas lahan mulai dari benih sampai membuahkan hasil yang disokong oleh kesesuaian lahan sesuai dengan syarat tumbuh tanaman.

Kegiatan pertaniaan khususnya bidang holtikultura (tanaman bunga,buah dan sayur) banyak menarik perhatian berbagai kalangan. Disamping untuk menyalurkan hobi, kegiatan ini juga dapat dapat dijadikan mata pencarian yang menghasilkan keuntungan. Komoditas holtikultura terutama sayur seperti kol, kentang, tomat, wortel,dan cabe sejak lama telah dibudidayakan oleh petani karena produk ini dibutuhkan hampir oleh setiap lapisan masyarakat sebagai menu hidangan sehari-hari (Agro Media, 2008).

Cabe adalah buah yang digolongkan sebagai sayuran maupun bumbu, tegak dengan batang berkayu, banyak cabang, serta ukuran yang mencapai tinggi 120 $\mathrm{cm}$ dan lebar tajuk tanaman hingga $90 \mathrm{~cm}$ (Agro Media, 2008). Cabe sebagai komoditi sayuran mempunyai nilai ekonomi yang cukup tinggi dibanding jenis sayuran lainnya.

Berdasarkan data statistik pertanian, produksi rata-rata cabe di kabupaten Solok periode 2010-2015 tercatat 19.836,4 ton per tahun. Jika setiap satu hektar lahan mampu menghasilkan cabe sebanyak 10 ton permusim dan dapat ditanami sebanyak tiga kali, dalam setahun dibutuhkan lahan penanaman cabai sebanyak 31.500-38.500 ha. Jika hanya ditanami sekali, dibutuhkan lahan 94.500-115.500 ha, dengan catatan produksi cabai mampu menghasilkan 10 ton per hektar terkena serangan hama dan penyakit (Redaksi Agromedia, 2008).

Kabupaten Solok merupakan daerah yang cocok untuk tumbuh dan berkembangnya tanaman cabe tepatnya di Kecamatan Lembah Gumanti, umumnya para petani masih menanam cabe merah secara tradisional dengan sistem tumpang sari bersama bawang merah. Kabupaten Solok dikenal sebagai 
daerah agraris, sehingga pertanian merupakan salah satu bidang potensial untuk dikembangkan dengan berbagai jenis tanaman yang diusahakan oleh petani di Kecamatan Lembah Gumanti kabupaten Solok.

Sedangkan pada tanaman cabe resiko kegagalan panen dan harga relatif stabil sehingga resiko yang dihadapi petani cabe tersebut sangat kecil. Tanaman cabe juga merupakan salah satu komoditas sayuran penting. Tanaman cabe memiliki potensi dan prospek yang baik untuk diusahakan.(Agromedia, 2008).

Berdasarkan hasil observasi yang telah dilakukan bahwa meningkatnya pendapatan petani cabe di Kecamatan Lembah Gumanti kabupaten solok, dengan bibit yang baik dan pendapatan yang memuaskan maka termotivasilah petani untuk tanaman cabe, dengan tanaman cabe ini bisa menyekolahkan anak-anak kesekolah yang lebih tinggi, dan cara panennya dilakukan 2 kali dalam satu minggu kalau buah cabenya banyak masak, untuk menggambil atau memetik buahnya dibantu oleh orang lain dan nantinya mereka mendapatkan upah dari pemilik cabe dan pendapatan lebih meningkat dari yang biasanya, untungnya bisa di tabungkan.

Peran petani sangat besar pengaruhnya terhadap kelancaran usaha pertanian, dalam hal ini keterampilan petani tersebut dalam usaha pertanian yang dilakukannya. Apabila petani tidak mempunyai keterampilan dalam usaha pertanian, maka mustahil hasil yang didapat akan memuaskan dan sesuai dengan yang diharapkan. Karena begitu besarnya peran petani dalam hal usaha pertanian, maka petani perlu dibekali keterampilan dalam hal usaha pertanian agar mereka tahu cara atau strategi dalam meningkatkan produksi yang dihasilkannya. Selain itu, petani harus bisa mengolah lahan dengan maksimal, agar nantinya tanaman menerima unsur hara yang cukup dan mampu menghasilkan produksi yang memuaskan (Agromedia,2008).

Pengelolahan lahan sangat penting, karena tempat dimana tanaman akan tumbuh. Apabila petani mengharapkan hasil yang memuaskan, maka lahan harus diolah semaksimal mungkin. Selanjutnya, perluasan areal tanam juga faktor penting dalam peningkatan hasil tanaman cabe. Jika petani mengharapkan hasil yang maksimal, maka petani harus bisa membuka lahan baru untuk tanaman cabe. Di dalam usaha tanaman cabe, produk yang dihasilkan harus bisa ditingkatkan. 
Karena, suatu langkah jika petani menginginkan hasil yang maksimal dalam usaha pertaniannya (Agro Media 2008).

Motivasi petani menanam cabe di Kecamatan Lembah Gumanti kabupaten Solok ini disebabkan oleh petani cabe supaya cabenya lebih bagus dan menghasilkan produksi cabe yang baik tapi itu semua tidak membuahkan hasil, karena pola usaha tani tanaman cabe biasa dilakukan pada lahan dengan luas kurang dari 0,3 hektar, lahan pertanaman seringkali belum siap akibat tingginya derajat keasaman $\operatorname{tanah}(\mathrm{pH}<7)$ dan mengandung penyakit (bakteri), benih yang digunakan petani adalah benih yang memiliki kualitas cabe sehingga produksi dan kualitas tinggi, sistem irigasi atau pengairan yang kurang baik, belum optimalnya pengendalian hama dan penyakit, dan belum adanya upaya penanganan panen dan pasca panen dengan baik. Hal ini mengakibatkan produktivitas menjadi tinggi dan memberikan keuntungan yang optimal bagi petani. Hasil usaha tani dengan pola seperti ini juga bisa diandalkan untuk memenuhi kebutuhan konsumsi dalam negeri, ekspor, dan industri pengolahan yang cenderung terus meningkat.

Berdasarkan latar belakang masalah di atas, penulis tertarik untuk meneliti. Motivasi Petani Menanam Cabe (Capsicumm Annum L) Di Kecamatan Lembah Gumanti Kabupaten Solok.

\section{METODOLOGI}

Penelitian ini dikategorikan kedalam jenis penelitian kualitatif. Menurut Moleong (2007) metode kualitatif adalah yang tidak mengadakan perhitungan atau menggunakan angka-angka, penelitian ini merupakan salah satu bentuk penelitian yang bertujuan untuk menggambarkan atau menuliskan motivasi petani cabe (capsicum annum 1) di kecamatan Lembah Gumanti kabupaten Solok.

Metode penelitian kualitatif adalah prosedur penelitian yang menghasilkan data deskriptif, ucapan atau lisan dan perilaku yang diamati dari orang-orang (objek) itu sendiri, pendekatan ini berlangsung menunjukkan setting dari individuindividu, tidak dipersempit menjadi variabel yang dipisah menjadi hipotesis melainkan dipandang sebagai bagian dari suatu keseluruhan (Moleong 2007).

Diperjelas lagi bahwa metode penelitian kualitatif sering disebut metode penelitian naturalistik karena penelitiannya dilakukan pada kondisi yang alamiah (natural setting), serta disebut juga metode etnografi, karena pada awalnya penelitian ini lebih banyak digunakan untuk penelitian bidang antropologi sosial 
yang disebabkan karena data yang kumpul dan analisisnya lebih bersifat kualitatif. (Sugiyono,2009:14).

\section{Lokasi Penelitian}

Lokasi penelitian ini adalah di Jorong Galagah kenagarian Alahan Panjang kecamatan Lembah Gumanti Kabupatan Solok. Penelitian ini bertujuan tentang motivasi petani menanam cabe di Kecamatan Lembah Gumanti Kabupaten Solok.

\section{Informan Penelitian}

Informan yaitu orang yang terlibat langsung dalam objek penelitian atau orang yang menjadi sumber informasi oleh peneliti sendiri, semua data dan keterangan yang dibutuhkan peneliti akan didapat dari informan dengan teknik dan cara yang sesuai. Penentuan informan diambil dengan teknik snowball sampling, yaitu teknik pengumpulan sampel yang mula-mula jumlahnya kecil, kemudian besar. Ibarat bola salju yang menggelinding yang lama-lama menjadi membesar. Dalam penentuan sampel, pertama-tama dipilih satu atau dua orang, tetapi karena dengan dua orang ini belum merasa lengkap terhadap data yang diberikan, maka peneliti mencari orang lain yang dipandang lebih tahu dan dapat melengkapi data yang diberikan oleh dua orang sebelumnya. Begitu seterusnya sehingga jumlah sampel semakin banyak (Sugiyono, 2013). Adapun yang menjadi informan dalam penelitian ini adalah petani cabe yang terdapat di kecamatan lembah gumanti kabupaten solok.

\section{Teknik Pengumpulan Data}

Teknik pengumpulan data penelitian ini yaitu dengan cara sebagai berikut:

1. Observasi dan pengumpulan data

Teknik ini digunakan untuk melihat dan mengamati kegiatan kehidupan masyarakat sehari-hari pada umumnya terhadap motivasi petani menanaman cabe di kecamatan lembah gumanti kabupaten solok dalam bentuk observasi lapangan terus terang.

2. Wawancara

Teknik wawancara adalah percakapan dengan maksud tertentu yang dilakukan oleh dua orang atau dua belah pihak yaitu pewawancara dengan pihak yang diwawancarai atau diminta informasinya.

Jenis wawancaran dalam bentuk (interviewer) wawancara semiterstruktur dalam hal ini peneliti dan pihak yang di wawancarai agak bebas namun tetap 
dalam konsep yang direncanakan dan mencatat hal-hal yang penting dari hasil wawancara dalam hal ini di maksud untuk mengetahui apa motivasi petani menanam cabe di kecamatan lembah gumanti kabupaten solok.

\section{Bahan visual}

Teknik bahan visual adalah teknik pengumpulan data berupa bahan fotografi yang terdiri dari foto-foto yang digunakan untuk mengabadikan proses dalam wawancara pada motivasi petani menanam cabe di kecamatan lembah gumanti kabupaten solok yang di lakukan masyarakat yang diteliti (Burhan, 2000:126127).

\section{Teknik Analisa Data}

Teknik analisa data yang penulis pakai adalah teknik analisa data dilakukan bersamaan dengan pengumpulan data yang mana analisa data yang mana analisa data kualitatif ini dikemukan oleh Miles dan Huberman dalam Sugiyono (2009:401), dilakukan secara interaktif melalui proses data reduction data,data display, verification dengan langkah-langkah sebagai berikut:

\section{Reduksi Data}

Merupakan langkah pengumpulan data atau jawaban yang diperoleh dilapangan dan kemudian di rangkum, memilih hal-hal yang pokok,memfokuskan pada hal-hal yang berkaitan dengan permasalah penelitian,yang mana data diperoleh dari informan (data primer) dan data-data dalam bentuk dokumen (data sekunder).

\section{Penyajian Data}

Merupakan langkah analisis data yang mengelompokan atau menyusun data yang di peroleh baik itu dari data primer dan data sekunder dalam bentuk uraian singkat berupa teks naratif, dan bagan yang gunanya agar memudahkan memahami data yang diperoleh.

\section{Verifikasi}

Verifikasi adalah langkah ke tiga dalam analisis data yang diperoleh dari data yang diperoleh dari data yang mana membuat suatu rangkai kedalam suatu bentuk kesimpulan data yang di dukung dengan bukti-bukti yang valid dan konsisten.

4. Membuat laporan 
Adalah merupakan akhir dalam melakukan analisis data yang mana membuat suatu rangkai kalimat dalam bentuk laporan yang diperoleh dari setiap pengalaman, dan kejadian dalam pengumpulan data di lapangan.

\section{Teknik Pemeriksaan Keabsahan Data}

Menurut Moleong (2010:179) pemeriksaan keabsahan data yang diperoleh akan dilakukan dengan beberapa cara antara lain: 1). Perpanjangan keikutsertaan, 2). Ketekunan pengamatan, 3). Triangulasi, 4). Pengecekan teman sejawat.

\section{Perpanjangan keikutsertaan}

Dalam penelitian ini, fungsi dari penelitian ini adalah sebagai instrumen,yang artinya keikutsertaan peneliti pada objek penelitian sangat berarti sekali dalam proses pengumpulan data.dalam proses pengumpulan data ini data harus benarbenar dapat dipercaya dan terbukti karena data ini diperoleh setelah mengalami proses perpanjang pengamatan terhadap data tersebut.

\section{Ketekunan pengamatan}

Ketekunan pengamatan bertujuan untuk menetukan ciri-ciri dan unsur-unsur dalam situasi yang relevan dengan persoalan dan isu-isu yang sedang di cari peneliti akan mengamati dan melihat secara spesifik tentang motivasi petani menanam cabe di kecamatan lembah gumanti kabupaten solok.

\section{Triangulasi}

Teknik triangulasi adalah teknik untuk memeriksa keabsahan data yang dimanfaatkan sesuatu diluar data itu,untuk keperluan pengecekan atau sebagai perbandingan terhadap data yang diperoleh. Triangulasi sumber,metode penyelidikan dan teori unruk sumber yang mana teori triangulasi sumber adalah peneliti mengecek kembali tingkat keberadaan suatu informasi berdasarkan waktu dan alat,baik pada saat yang sama maupun saat yang berbeda. Sedangkan dalam triangulasi teori penulis melihat pada peristiwa dalam perspektif teori, pandangan dan pendapat orang lain dalam bentuk tulisan.

Triangulasi adalah untuk memeriksa keabsahan data yang memanfaatkan suatu keabsahan data itu untuk keperluan pengecekan atau sebagai perbandingan terhadap data yang diperoleh. (Moleong, 2010:330)

\section{PEMBAHASAN}


Berdasarkan hasil temuan di lapangan dan sesuai dengan tujuan penelitian untuk mengetahui dan menganalisa informasi tentang motivasi petani menanam cabe (Capsicum Annum L) di kecamatan Lembah Gumanti kabupaten Solok, dapat diambil kesimpulan sebagai berikut:

Pertama, Motivasi petani dalam Pengolahan lahan dalam menanam cabe, cara pengolahan lahan pada tanaman cabe adalah dengan cara pencangkulan, pembuatan bedengan, pengapuran, pemupukan.Pencangkulan di lakukan pada awal penanam tanaman cabe, dan pemberian pupuknya juga dilakukan pada awal atau pertama dari penanam cabe, Dibandingakan tanaman lainnya tanaman cabe tidak sulit dalam pengolahan lahan dan pemberian pupuk. Pengolahan lahan dapat membentuk dan memilihara pertumbuhan tanaman menjadi baik. Dengan pengolahan yang mudah maka termotivasilah petani untuk menanam tanaman cabe,di bandingkan tanaman lainnya seperti tanaman bawang merah, tomat dan kol. Dan cara pengolahanhnya juga sangat meringkan petani menanam cabe dibandingkan tanaman lainnya dilihat pada perawatan awalnya saja sulit,tetapi untuk selanjutnya tidak terlalu sulit, dan tidak menggunakan waktu yang begitu panjang. Dan bisa untuk membantu atau meringkan petani dalam perawatan tanaman cabe.

Dalam proses pertanian cabe ini ada dua cara yang dilakukan oleh petani yang dilakukan sendiri oleh petani dan memperkerjakan orang lain sesuai dengan luas lahan yang dimiliki petani, Petani yang memiliki lahan yang sempit hanya dilakukan sendiri yang dibantu oleh anggota keluarganya, dan bagi petani yang memiliki lahan luas dikerjakan dengan memperkerjakan orang lain dengan sistim upah.

Pengolahan lahan diawali dengan pembersihan lahan dari sisa-sisa tanaman sebelumnya. Bila perlu, sisa tanaman yang cukup banyak dijadikan kompos, lalu dikembalikan ke dalam tanah. (Purwono dan Hartono,2007:28).

Kedua, Motivasi petani menanam cabe dalam tingkat produksi dapat dilihat pada tingkat pendapatan dan penghasilannya yang sudah bisa memenuhi kebutuhan sehari-hari, dan membiayai anak untuk sekolah dan juga bisa membeli peralatan rumah tangga dan membeli barang-barang yang berharga untuk sebagai simpanan. Pendapatan petani pada saat sekarang ini sudah meningkat dibandingkan dengan yang sebelumnya,dan pendapatan yang di dapatkan pada 
awal panen yaitu dilihat dari hasil panen per minggunya ,dalam satu minggu petani menghasilkan atau mendapatkan uang dari hasil panen tanaman cabe Rp.1.000.000,00 setiap kali panen kalau hasil panen nya banyak maka hasil dari panen juga banyak, maka dari itu termotivasilah petani untuk menanam cabe dengan tingkat pendapatan yang tinggi. Dan sudah memuaskan bagi petani yang menanam cabe. Dibandingkan hasil tanam yang sebelumnya,pendapatan petani meningkat dan memuaskan bagi petani yang menanam cabe.

Penelitian ini sesuai dengan Assauri (2008) bahwa produksi adalah merupakan kegiatan yang berhubungan dengan usaha untuk menciptakan dan menambah kegunaan atau utilitas suatu barang dan jasa .Assauri (2008) seperti diketahui kegunaannya atau utilitas dibedakan atas karena bentuk, tempat, waktu dan pemilikannya. Faktor-faktor produksi terdiri atas tanah atau alam, modal, tenaga kerja dan keterampilan teknis dan teknologi.

Ketiga, Motivasi petani menanam cabe dengan harga yang tinggi,dengan harga yang tinggi pendapatan petani sudah meningkat karena dengan harga cabe yang sudah meningkat di bandingkan dengan harga sayur yang lainnya,makanya petani sangat termotivasi untuk menanam cabe. Harga yang tinggi sangat berpengaruh untuk memenuhi kebutuhan sehari-hari bagi petani dimana petani sangat membutuhkan biaya untuk memenuhi kebutuhan sehari-harinya, harga cabe pada saat sekarang ini sangat membantu petani menanam cabe.

Dengan harga yang tinggi selain itu petani juga bisa menyekolahkan anakanaknya ke sekolah yang lebih tinggi ke luar daerah alahan panjang contoh nya ke padang,bukit tinggi,dan jakarta. Maka dari itu petani sangat termotivasi untuk menanam cabe dengan adanya peningkatan harga cabe pada saat sekarang ini, petani cabe jadi senang dan tambah semangat.

Menurut swasta (2000) pengertian harga adalah sebagai nilai suatu barang atau jasa yang diukur dengan sejumlah uang dimana berdasarkan nilai tersebut seseorang atau perusahaan bersedia melepaskan barang atau jasa yang dimiliki kepada pihak lain. Harga merupakan suatu moneter atau ukuran lainnya (termasuk barang dan jasa) yang ditukarkan agar memperoleh hak kepemilikan dan penggunaan suatu barang atau jasa.(Tjiptono,2001:151)

Kesejahteraan petani di Kecamatan Lembah Gumanti tergantung pada harga yang tinggi. Semenjak tanaman cabe mulai berkembang kehidupan sosial 
ekonomi masyarakat mulai meningkat, hal ini ditandai dengan sudah banyak anak petani cabe yang telah melanjutkan pendidikan ke jenjang yang lebih tinggi dan juga dilihat dari segi perumahan yang telah banyak memiliki perumahan permanen.Berbicara mengenai gaya hidup suatu masyarakat tidak terlepas dari keadaan ekonomi masyarakat. Masyarakat di Kecamatan Lembah Gumanti yang berprofesi sebagai petani cabe, walaupun masih ada yang berprofsesi sebagai pedagang, pegawai Negeri Sipil (PNS), buruh, tukang ojek, tetapi hanya dalam skala kecil. Pada umumnya masyarakat memiliki mata pencaharian sebagai petani cabe. rumah merupakan tempat berkumpulnya anggota keluarga dan merupakan tempat untuk melangsungkan proses kehidupan baik sebagai tempat tinggal maupun sebagai tempat bermusyawarah.

Pengaruh dalam bidang pendidikan di Kecamatan Lembah Gumanti dapat dilihat dari banyak anak-anak yang melanjutkan pendidikan ketingkat yang lebih tinggi baik di Kecamatan Lembah Gumanti maupun di luar kecamatan lembah gumanti seperti ke padang, ke solok, padang panjang, jawa, Sumatera utara. Hal ini dikarenakan pendapatan yang diperoleh dari pertaniaan cabe mereka dapat menabung sedikit demi sedikit sehingga anaknya dapat mendapatkan sekolah yang diinginkan. Menurut Nitisemito (2000) pengertian harga adalah sebagai nilai suatu barang atau jasa yang diukur dengan sejumlah uang dimana berdasarkan nilai tersebut seseorang atau perusahaan bersedia melepaskan barang atau jasa yang dimiliki kepada pihak lain.

\section{KESIMPULAN}

Berdasarkan hasil penelitian dan pemahaman dalam penelitian mengenai motivasi petani menanam cabe di kecamatan lembah gumanti kabupaten solok dapat disimpulkan sebagai berikut:

1. Pengolahan lahan yang tidak terlalu sulit sangat memotivasi petani dalam menanam cabe, Petani tidak ada beban maupun rintangan untuk pengolahan lahan untuk menanam cabe.

2. Tingkat produksi yang meningkat sangat memotivasi petani dalam menanam cabe, sehingga meningkatkan pendapatan petani dan memenuhi kebutuhan sehari-hari. 
3. Harga jual cabe yang tinggi sangat memotivasi petani dalam menanan cabe, sehingga meningkatkan kemampuan ekonomi petani menanam cabe di galagah.

1. Disarankan kepada petani cabe lebih ditingkatkan lagi kualitas tanaman cabe agar harga harganya tetap tinggi.

\section{DAFTAR PUSTAKA}

Sugiyono. 2009. Metode penelitian kuntitatif \& kualitatif dan R\&D. Bandung : Alfa Beta.

Sugiyono. 2013. Metode Penelitian Kuantitatif,kualitatif Dan $R \quad \& \quad B$. Bandung:Alfabeta.

Tim Bina Karya Tani. 2008. Pedoman Bertanam Cabai. Bandung : Yrana Widya

Tim Redaksi Agro Media. 2008. Panduan Lengkap Budidaya dan Bisnis Cabai. Jakarta : PT Agro Media Pustaka. 